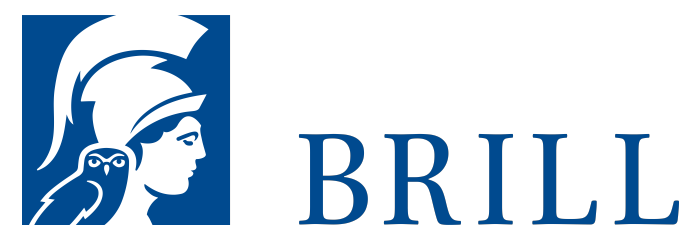

\title{
Index to Periodical Literature for the Study of the New Testament
}

\section{Author: Mills}

This volume includes more than 15 ,000 citations to periodical literature published during the twentieth century. Citations are included for each of the books and of the New Testament and these are aranged in canonical order. The specific references are set forth within each canonical book by textual unit. The arrangement of these textual units is the longer before the shorter. There are approximately 175 periodicals included. While the major emphasis is upon English language journals, there are several different language groups represented. The journals included are representative of various theological perspectives. The work includes a comprehensive author index.

Index to Periodical Literature for the Study of the New Testament has been selected by Choice as Outstanding Academic Title (2005).

\section{Readership}

Professional researchers and graduate students (via reference libraries). "Scholarly" pastors engaging in sermon preparation. Picture material.

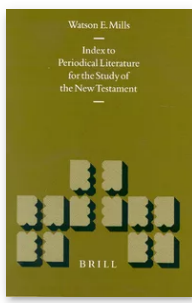

Pages: xviii, $135^{\circ}$ pp.

Language: English

Subjects: New

Testament \&

Early Christian Writings,

Biblical Studies, General, Biblical Studies

Publisher: Brill

Series:

New Testament

Tools, Studies

and Documents,

Volume: 31

E-Book (PDF)

Released online:

o1 Aug 2003

ISBN: 978-90-

47-41228-1

List price

USD $\$ 514.00$

Hardback

Publication date:

14 Nov 2003

ISBN: 978-90o4-12616-9

List price

USD $\$ 514.00$ 
Watson E. Mills, Ph.D. (1973) in NT Literature, Baylor University, is Professor of NT Studies at Mercer University. He is Editor of the Mercer Dictionary of the Bible and Mercer Commentary of the Bible, and an update of Periodical Literature on Christ and the Gospels (Brill, 1998).

For more information see brill.com

Order information: Order online at brill.com +44330 333 oo49 | customerservices@brill.com Submission information: brill.com/authors

Titles published by Brill | Fink, Brill | mentis or Brill | Schöningh: +49(o)71 5413279216 | brill@brocom.de 